\title{
A Multi-Species Etho-Ethnographic Approach to Filmmaking
}

\author{
Natasha Fijn
}

Through the filming of herders and herd animals within a multi-species hybrid community - essentially two herding encampments in Mongolia-I provide an example of an alternative methodological approach to both ethnographic filmmaking and multi-species research. This paper is a call for scholars engaging in the exciting and emerging area of multi-species ethnography to adopt a multisensory, etho-ethnographic approach to filmmaking in the field with attention to both visual and auditory communication between human and non-human agents.

The paper includes links to video segments from footage filmed in the Khangai mountains of Mongolia. Through a description of the stylistic and logistic techniques employed while filming these key video segments, this paper demonstrates an original approach to the study of humans and other animals in the production of video-based, multi-species etho-ethnography, accompanied by a description of how filmmaking can be used in conjunction with participant observation as a means of engaging in this kind of cross-disciplinary research in the field. My approach includes an orientation towards phenomenology and an attention to bodily and sensory ways of being in the world. ${ }^{1}$

The first part of the paper foregrounds how my work resonates within the emerging field of multi-species ethnography and how my filmmaking and research have been influenced by David MacDougall's theoretical and practical approaches to filmmaking, with particular reference to his Doon School Series of films. The second part of the paper provides an explanation of my own filmmaking approach through links to three separate online video segments: 'Saikhanaa and the Calves', 'Lhagva the Herder' and 'Training for Naadam'.

\footnotetext{
1 See Bateson, G. 1972, Steps to an Ecology of Mind, Ballantine Books, New York; Ingold, T. 2000, The Perception of the Environment: Essays on livelihood, dwelling and skill, Routledge, New York; von Uexküll, J. 1957, 'A stroll through the worlds of animals and men: a picture book of invisible worlds', in C. H. S. Schiller (ed.), Instinctive Behaviour: The development of a modern concept, International University Press, New York, pp. $5-80$.

2 Media files can be viewed by going to the 'Perspectives on Ethnographic Film' page on the ANU E Press website at http://epress.anu.edu.au/titles/humanities-research-journal-series/humanities-research-vol-xviiino-1-2012
} 


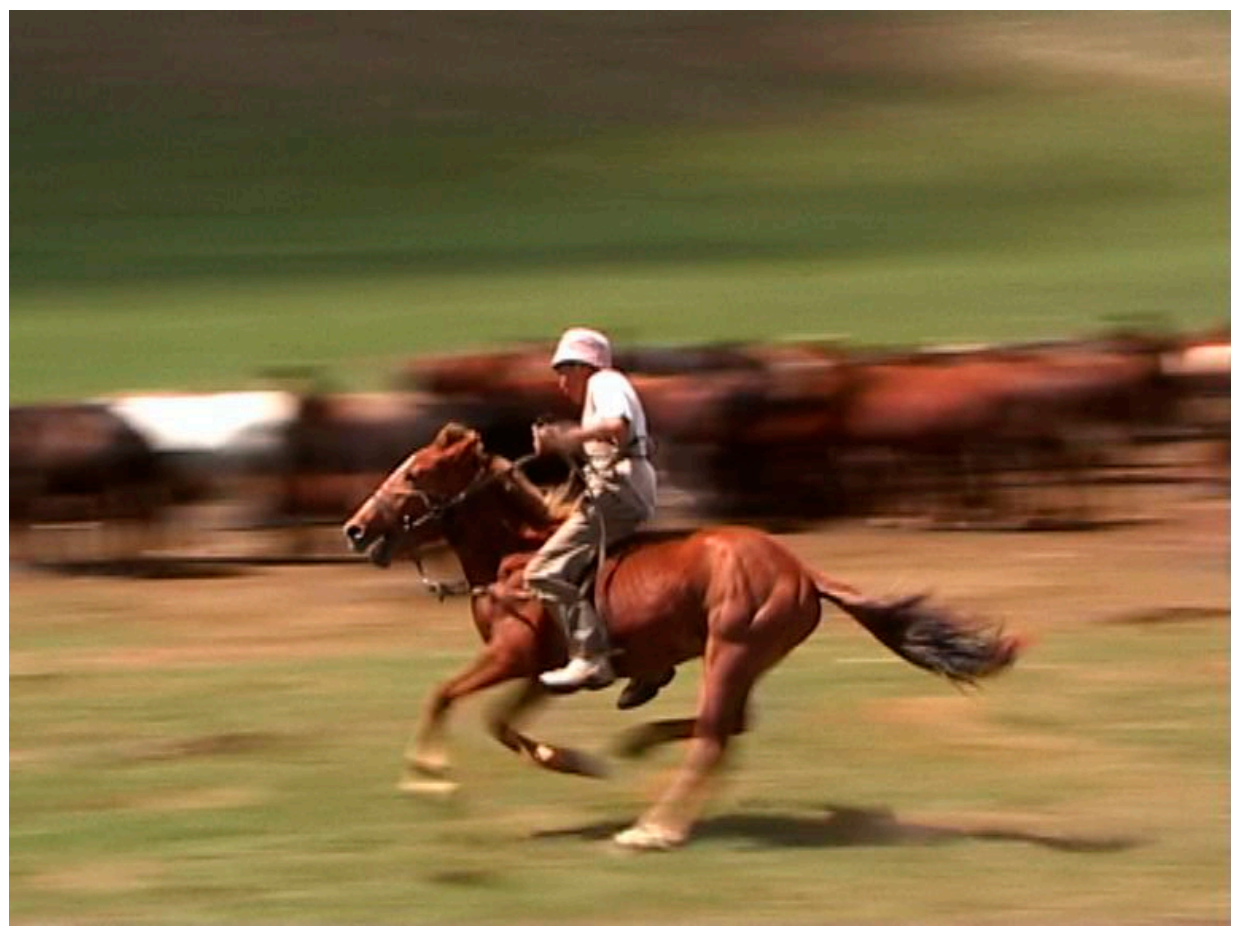

Figure $1 \mathrm{~A}$ Training gallop for the summer Naadam (festival). Still image from 'Training for Naadam'

\section{Background}

When starting my anthropologically based $\mathrm{PhD}$ research - an investigation into domestication as an ongoing process between herders and herd animals in Mongolia - my initial intention was to use video as a methodological tool during my fieldwork, much as a zoologist uses video: to collect data on social interactions and behaviour with the aim of being as objective as possible. My approach has changed considerably, however, through the influence of David and Judith MacDougall's filmmaking philosophy and practice.

In previous field-based ethological research, I had become disillusioned with the disciplinary restrictions on the level of engagement with my research subjects. The aim of that research was to investigate how kea (Nestor notabilis), a mountain parrot, learned in social situations and to test their problem-solving capabilities. I was to observe the behaviour of the animal in question but was to avoid direct contact with individuals during field experiments. Over time the population became habituated to my presence and my whistles but there was an expectation not to engage with the kea on a personal level. Contrary to 
this species-level, or population-scale, approach, kea are particularly curious individuals and would often initiate communication and interaction with me as an individual of their own volition, investigating my shoelaces or flying onto my head and shoulders. Through this ethological fieldwork, I had learnt skills in long-term observation but had not had the opportunity to participate crossspecifically, across species boundaries, as anthropologists do cross-culturally. ${ }^{3}$

The use of a video camera for obtaining ethological data is normally restricted to having the camera fixed on a tripod, while the person running the camera remains silent and as immobile as possible throughout. The camera may even be left in a fixed position with the researcher viewing the footage remotely in order to ensure that the animal is likely to behave as it would 'in the wild' without any human presence. Such circumstances are not entirely realistic, however, as kea, for instance, often engage with humans in their quest for food or are intent on investigating any object that is colourful and new in their immediate environment, such as windscreen wipers, bicycle seats, rubbish bins, a vacant mountain hut or a sleeping person's nose. They do not live in an enclosed 'wilderness', isolating themselves from other beings, but inhabit a diverse, multi-species world, which includes contact with humans.

My experience with the use of a camera on a tripod to obtain scientific data brings to mind a discussion between Gregory Bateson and Margaret Mead where they argue with one another from quite different perspectives on the use of a camera within anthropological research. Mead argues for the recording of ethnography without any intervention from the filmmaker, where she envisages the way of the future would be a 360-degree camera. Bateson argues that he is 'talking about having control of a camera. You're talking about putting a dead camera on top of a bloody tripod. It sees nothing.' ${ }^{4}$ I was determined in my next project - encompassing a multi-species research approach - to use the camera without a tripod, for similar reasons to Bateson.

A hand-held camera, in my experience, enables the researcher to make more informed decisions about what is relevant to capture and what one is capable of capturing in any given situation. Instead of striving for an unattainable objectivity, I was aware that my use of a video camera would inevitably result in my own subjective observations. Vertov neatly sums up the subjective process

\footnotetext{
3 Beyond the experimental research parameters of the project, I did of course engage with the kea in a different manner when they came to my window or landed on the roof of the mountain hut I was living in. I found these instances some of the most rewarding, in terms of gaining cross-species understanding.

4 Bateson, G. and Mead, M. 1976, 'For God's sake, Margaret', CoEvolution Quarterly, vol. 10, no. 21, pp. 3244. (Excerpts reprinted as Mead, M. and Bateson, G. 1977, 'Use of the camera in anthropology', Studies in the Anthropology of Visual Communication, vol. 4, no. 2, pp. 78-80.) See also Mead, M. 1995, 'Visual anthropology in a discipline of words', in P. Hockings (ed.), Principles of Visual Anthropology, [Second edn], Walter de Gruyter, Berlin, pp. 3-10.
} 
within filmic-based research by the comment: 'I edit when I choose my subject (from among thousands of possible subjects), and I edit when I observe (film) my subjects (to find the best choice among a thousand possible observations). ${ }^{5}$

\section{Multi-Species Etho-Ethnography}

There has been an emerging interest in multi-species, or interspecies, ethnography — work that is inclusive of non-human beings within anthropology. ${ }^{6}$ 'Multi-species' is a term derived from zoology and ecology but has been adopted by anthropologists to describe a focus that is not only on the human but also on our relationship and connections with non-human others. ${ }^{7}$ Previously nonhumans in anthropology appeared as symbols, metaphors or tools for human social engagement but animals and plants are now becoming agents in their own right. Anna Tsing writes with regard to this new genre:

It allows something new: passionate immersion in the lives of the nonhumans being studied. Once such immersion was allowed only to natural scientists, and mainly on the condition that the love didn't show. The critical intervention of this new science studies is that it allows learnedness in natural science and all the tools of the arts to convey passionate connection. ${ }^{8}$

My approach to filming herders and herd animals within a multi-species hybrid community - essentially two herding encampments in Mongolia - is an example of an ethno-ethological approach espoused by Dominique Lestel and colleagues. Their paper outlines new terms for studying humans and non-human animals, including elements of both ethology and ethnology, with a tradition rooted in phenomenology and biosemiotics. They use the term ethno-ethology:

[T] his new ethnological approach sets out to integrate the analysis and understanding of our knowledge of the living world, its organization as well as its application, in an approach to the interactive relational system

\footnotetext{
5 Vertov, 1923, quoted in Rouch, J. 1995, 'The camera and man', in Hockings, Principles of Visual Anthropology, p. 90.

6 See special multi-species issues in Kirksey, S. B. and Helmreich, S. 2010, 'The emergence of multispecies ethnography', Cultural Anthropology, vol. 25, no. 4; and Rose, D. B. and van Dooren, T. 2011, 'Unloved others: death of the disregarded in a time of extinctions', Australian Humanities Review, vol. 50.

7 Donna Haraway is one of the key writers relating to this 'species turn' in anthropology; see Haraway, D. 2008, When Species Meet, University of Minnesota Press, Minneapolis; and Haraway, D. 2003, The Companion Species Manifesto: Dogs, people and significant otherness, The Prickly Paradigm Press, Chicago.

8 Tsing, A. 2011, 'Arts of inclusion, or, how to love a mushroom', Australian Humanities Review, vol. 50, p. 19.
} 
that links humans and non-humans. At the same time, it grants all living beings the status of relational beings, that is, agents interacting on the phenomenon of 'culture' that was hitherto reserved for human beings. ${ }^{9}$

There are a number of observational-style ethnographic films about herding culture but most tend to focus on the herders themselves with the animals they herd as peripheral elements in relation to the central subject matter of the film (the human Other). Examples of such films are David MacDougall's To Live with Herds (1973) and his later Tempus de Baristas (1993). ${ }^{10}$ One recent observational film that engages in a multi-species landscape is Sweetgrass. ${ }^{11}$ This film was 'recorded' by Lucien Castaing-Taylor and here the emphasis is just as much on the recording of the audio as on the visual imagery. ${ }^{12}$

Similar to my film Khangai Herds, in Sweetgrass, instead of a reliance on commentary or interviews, or even the social engagement between people, the focus is on the sounds of the humans and other animals - in this instance, the communication between the cowboys and their horses, dogs and all-important sheep. Through radio microphones on the cowboys, Lucien Castaing-Taylor records the audio of the soft encouragement of one and the frustrated and angry swearing of another herder towards the flock of sheep. The sounds add to an embodied feeling of being somehow a part of the muster with the barking of the dogs, the endless calling of mother sheep to their nearly fully grown lambs and a nervous horse's hooves as they clatter across a rushing stream, accompanied by the soft sounds of encouragement from its rider. In my view, in a complex multi-species landscape, these embedded sounds are the ones that are important, not detailed conversation or interviews telling the audience what is unfolding. Ilisa Barbash and Lucien Castaing-Taylor explore the interspecies relationship, giving agency to the sheep both as individuals and as a herd, much as was my intention when filming Mongolian herd animals.

\footnotetext{
9 Lestel, D., Brunois, F. and Gaunet, G. 2006, 'Etho-ethnology and ethno-ethnology', Social Science Information, vol. 45, no. 2, p. 168. See also Lestel, D. 2006, 'Ethology and ethnology: the coming synthesis. A general introduction', Social Science Information, vol. 45, no. 2, pp. 155-77.

10 MacDougall, D. 1973, To Live with Herds, [70 mins], University of California, Los Angeles; MacDougall, D. 1993, Tempus de Baristas, [100 mins], Istituto Superiore Regional Etnografico/Fieldwork Films and BBC Television.

11 Barbash, I. and Castaing-Taylor, L. 2009, Sweetgrass, [109 mins], Cinema Guild, USA. For an eloquent review of this film, see Grimshaw, A. 2011, 'The bellwether ewe: recent developments in ethnographic filmmaking and the aesthetics of anthropological inquiry', Cultural Anthropology, vol. 26, no. 2, pp. 247-62. 12 Barbash and Castaing-Taylor have written an introductory guide to filmmaking; see Barbash, I. and Taylor, L. 1997, Cross-cultural Filmmaking: A handbook for making documentary and ethnographic films and videos, University of California Press, Berkeley.
} 


\section{Observational Filmmaking}

Back in 2004, I had recently started a PhD at The Australian National University. I found myself at an intensive eight-hour screening, featuring five films from David MacDougall's Doon School Series. ${ }^{13}$ Just as I would have images of my ski tips when I closed my eyes after a day's skiing, I had images of the Doon School behind my eyelids that evening. The screening was a deeply immersive experience and completely changed my approach towards the use of video in future research. Through the films I felt that I had grown to know some of the boys in the films as real people and could gain a quality of understanding from the Doon School films that I could not gain from other documentary genres. It was a good introduction to an observational style of ethnographic filmmaking, a style that I could feasibly undertake and integrate with a written monograph. ${ }^{14}$

David MacDougall's observational style means that his filmmaking can be both interpretative and revelatory. His films are not explanatory but are about inquiry and investigation, requiring the audience to think harder while watching the film and to pay attention to detail rather than to make broad judgments and conclusions. Here was a more embodied, phenomenological approach to filmmaking, where the focus could be on details of bodily engagement, rather than verbal dialogue, without the need for an overriding didactic form of narration. As Anna Grimshaw points out, in relation to one of the Doon School films, With Morning Hearts, 'we are left to judge the evidence that is presented to us in the form of movements, gestures, actions, responses to people and situations. Much of it is non-verbal and implicit.' ${ }^{15}$ I could see the potential for this style of filmmaking to be used in the often non-verbal, physical communication between humans and other animals.

This kind of ethnographic filmmaking is not just a means of presenting the results of research already attained, or aspiring towards an objective means of collecting data, but involves the researcher/filmmaker as an active participant and observer. While still in the process of editing the Doon School Series in 2001, David MacDougall writes how the advent of digital video 'has brought the ethnographic filmmaker's situation closer to that of the classical anthropological

13 The Doon School Series, distributed by Ronin Films, consists of Doon School Chronicles (2000), With Morning Hearts (2001), Karam in Jaipur (2001), The New Boys (2003) and The Age of Reason (2004).

14 I was also influenced by other ethnographic filmmakers connected with The Australian National University, particularly Gary Kildea, Judith MacDougall, Ian Dunlop and Pip Deveson. For an insight into the range of visual anthropology-related research undertaken by PhD students in 2007, see Bexley, A. and Fijn, N. (eds) 2007, 'Special Issue: Visual anthropology', The Asia Pacific Journal of Anthropology, vol. 8.

15 Grimshaw, A. 2002, 'From observational cinema to participatory cinema-and back again? David MacDougall and the Doon School project', Visual Anthropology Review, vol. 18, nos 1-2, pp. 80-92. For an interesting email discussion regarding the Doon School project, particularly in relation to Anna Grimshaw's review of With Morning Hearts, see MacDougall, D. and Grimshaw, A. 2002, 'Exchange of emails between David MacDougall and Anna Grimshaw', Visual Anthropology Review, vol. 18, no. 12, pp. 94-101. 
fieldworker, engaged in participant observation. It has also brought ethnographic filmmaking closer to the ideal of a more personal camera envisaged by the "direct cinema" filmmakers of the 1960s.' ${ }^{16}$

The films in the Doon School Series were the first where David MacDougall worked with digital video, rather than film. ${ }^{17}$ David MacDougall also worked independently throughout the entire project (whereas previously he had worked with Judith MacDougall or other filmmakers and anthropologists). Within my own project, with the aid of a compact video camera and a laptop with professional editing capabilities, I could see that I could independently undertake the entire filmmaking process from conducting preparatory research, filming while researching in the field and editing the footage in post-production, to the final presentation of the material. This meant that I was free to make my own decisions along the way and could respond to the herders and herd animals without the inevitable change in social dynamics that an additional foreigner would bring to both the research and the filming. MacDougall noticed the difference between working individually in comparison with working with another filmmaker or anthropologist: 'the result was a different kind of rapport...those being filmed are quick to sense that even two people filming them form a closed circle, with its own internal interactions.' ${ }^{18}$

David MacDougall explains his approach to the Doon School project within a chapter entitled 'Doon School reconsidered':

I felt that filming should be an inquiry leading to a structure, not a structure demonstrating the ideas I had started with. I wanted to find out what it was possible to learn about a school by filming it. When students asked me what I was doing, I told them I was studying the life of the school, but instead of writing a book about it I was going to try to write it with my camera. ${ }^{19}$

Essentially I had a similar goal to David MacDougall (to use video as a mode of inquiry) but the presentation of the material would be through a text-based monograph, Living with Herds in Mongolia, with an integration of the filmic material in some meaningful way. ${ }^{20} \mathrm{I}$ made a 90-minute observational film,

\footnotetext{
16 MacDougall, D. 2001, 'Renewing ethnographic film: is digital video changing the genre?', Anthropology Today, vol. 17, no. 3, p. 16 .

17 For an insight into David MacDougall's approach to earlier films, made with Judith MacDougall, refer to MacDougall, D. 1998, Transcultural Cinema, Princeton University Press, Princeton, NJ; and to the MacDougalls' teacher Colin Young's paper: Young, C. 1995, 'Observational cinema', in Hockings, Principles of Visual Anthropology, pp. 99-113.

18 MacDougall, 'Renewing ethnographic film', p. 20.

19 MacDougall, D. 2006, The Corporeal Image, Princeton University Press, Princeton, NJ, p. 122.

20 As early as 1942, Gregory Bateson and Margaret Mead integrated the use of film and photography with written ethnography; see Bateson, G. and Mead, M. 1942, Balinese Character: A photographic analysis, New York Academy of Sciences, New York.
} 
Khangai Herds, focusing on the same themes of cross-species social engagement and coexistence as my etho-ethnography in the text. The two mediums were linked by references to segments of the film in the text. ${ }^{21}$

This paper (and indeed this entire Humanities Research journal issue) is a further exploration of linking text with filmic-based online segments. Below I will discuss my filmic and etho-ethnographic intentions behind three separate video segments. The three segments are representative of different elements of the herders' and herd animals' domestic coexistence.

\section{Three Etho-Ethnographic Examples}

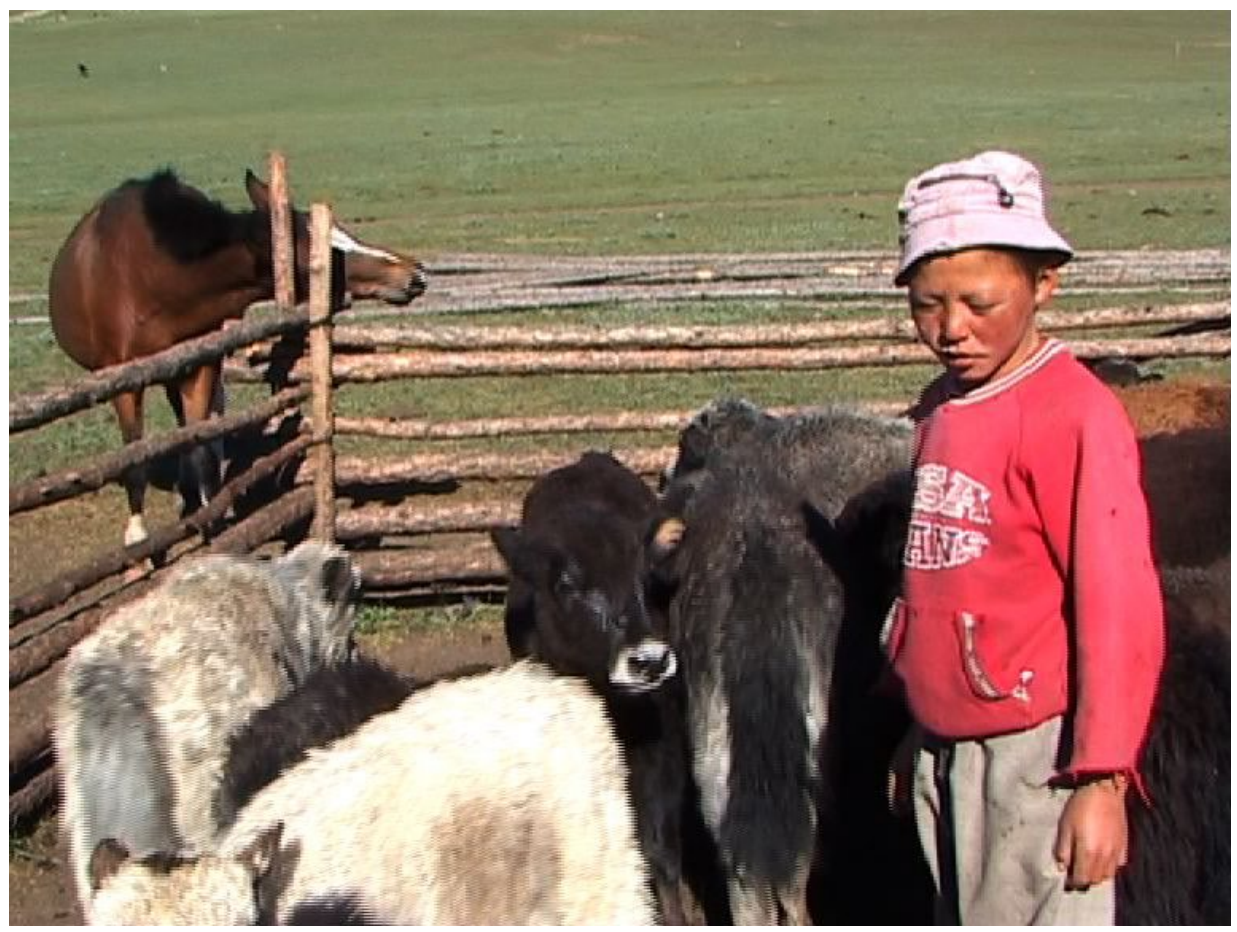

Figure 2 Still image from Khangai Herds Segment 2: Saikhanaa and the Calves

\section{View Khangai Herds Segment 2: Saikhanaa and the Calves ${ }^{22}$}

21 This research has since been published as a book; see Fijn, N. 2011, Living with Herds: Human-animal coexistence in Mongolia, Cambridge University Press, New York. Within the book there are footnote references linking to online video segments, providing key illustrative examples to accompany the text. This paper differs from my thesis and the subsequent book in that it features my filmic intentions through a detailed explanation of the three online video segments.

22 View associated media files via the ANU E Press website at http://epress.anu.edu.au/titles/humanities- 
The video segment 'Saikhanaa and the Calves' is about the intertwined lives of Saikhanaa and the cattle he engages with every day of the year. The sequence begins with the main protagonist of the first part of Khangai Herds, the young herder Saikhanaa, cantering on horseback away from the camera. The next scene is the arrival of a yak bull to Choijo's summer encampment, followed by the rest of the herd. The yak (or sarlag) arrives before the rest of the herd with purple tongue extended, panting. This is an introduction to the pace of the film and the quietness of the audio with minimal background noise - an unusual lack of traffic noise, machinery or passing aeroplanes. Gradually there is the sound of many hooves approaching and the odd sarlag grunt. Here, my intention was for the viewer to engage with the multi-species landscape: Saikhanaa on horseback, the male sarlag, followed by the cows and the distinctive accompanying sounds.

In the next scene, Saikanaa's mother enters the frame leading a calf, a cow recognises that this is her calf and comes over for a sniff, calf and human head in different directions, as the calf starts to follow its mother. The visual image is accompanied by the clanging of old-style milk containers and the whistling and calling of Saikhanaa to the herd outside the frame. These initial shots are framed at a wide angle and at a distance with the intention of conveying the general atmosphere in the morning before milking begins.

We are then amongst the herd as Saikhanaa's mother hand milks a cow, while another sarlag chews her cud waiting to be milked. We move to more activity as the milking starts in earnest, with multiple herders milking and cows vocalising to their calves. Some of the shots are at the height of the cows (and the women milking), to give an indication of what it is like to be amongst a herd of sarlag during milking time. The milking process is very much a part of the everyday routine in the summer within Choijo's encampment.

Part of my focus on Saikhanaa was to show just how hard he worked while still a boy and how skilled he is at handling the animals. Saikhanaa would prepare the cows for milking by taking the calves to feed from its mother's udder and by hobbling each cow's legs in preparation for milking. I would undertake these same tasks when not filming. Saikhanaa would always prepare the cows that Naraa would milk. I give an indication of this through a scene where Naraa asks Saikhanaa to hurry and to take the calf away so that she can get on with milking. Milking is serious business, as it is the main source of food for the extended family.

I film from inside the calf pen as Saikhanaa selects a calf to take to its mother. This was to convey the perspective of the calves as one-by-one they are called 
to the gate and led to feed from their mother. I first wanted to indicate to the viewer how the calves knew their own names, then later how Saikhanaa knew the names of each calf and their respective mother.

One of the few scenes where I engage in a more reflexive manner is when I encourage Saikhanaa as he names the calves and their mothers. As Saikhanaa is not outspoken, or particularly talkative, I wanted to encourage him to continue with his kinship connections. When Saikhanaa indicates the names of the calves directly to camera (to the author behind the camera), he does not just point to the calves from a distance. Saikhanaa climbed inside the calf's pen with the calves and makes contact with them with a hand or foot as he names them. One viewer after a public screening commented that he thought Saikhanaa was being rough with the calves, but this was not my impression in the field, as they are used to this degree of contact with individuals from the family, particularly Saikhanaa. The calves are not fearful of Saikhanaa, as they have grown up from birth being handled by him and they know him just as well as the other cattle in the herd.

A couple of shots show how Saikhanaa handles individual calves, some of whom are quite large in relation to his own body weight. He negotiates this by pushing them along with his whole body. There is constant bodily engagement with the animals, where communication is not just linguistic or verbal but also kinaesthetic. ${ }^{23}$ This is contrasted with his whistles to the herd as a whole as they leave the milking area. The milking scenes are not just about engaging with the footage in a visual sense but also about listening to the subtle vocalisations and communication between individual herders and individual cattle.

My knowledge of the daily milking routine, through active participant observation in the milking process, meant that I too knew the individual names of herders, cows and calves. I knew the process intimately, which meant that I could direct my focus on the filming itself, rather than on what may be happening next within the milking routine. Through participating in the milking routine throughout each day, the cattle knew my individual scent and were no longer wary of my presence. I could gauge how close I could film with the camera and felt at ease with my focus being within the viewfinder of the camera, rather than on what was happening on either side or behind me. I would not always have the camera with me but would choose a day when the weather was not too blustery or when I knew that the extended herding family had enough people to carry out the milking without my help while I was occupied with the camera.

23 See also Fijn, N. 2007, 'Filming the significant other: human and non-human', Asia Pacific Journal of Anthropology, vol. 8, no. 4, pp. 297-307. 


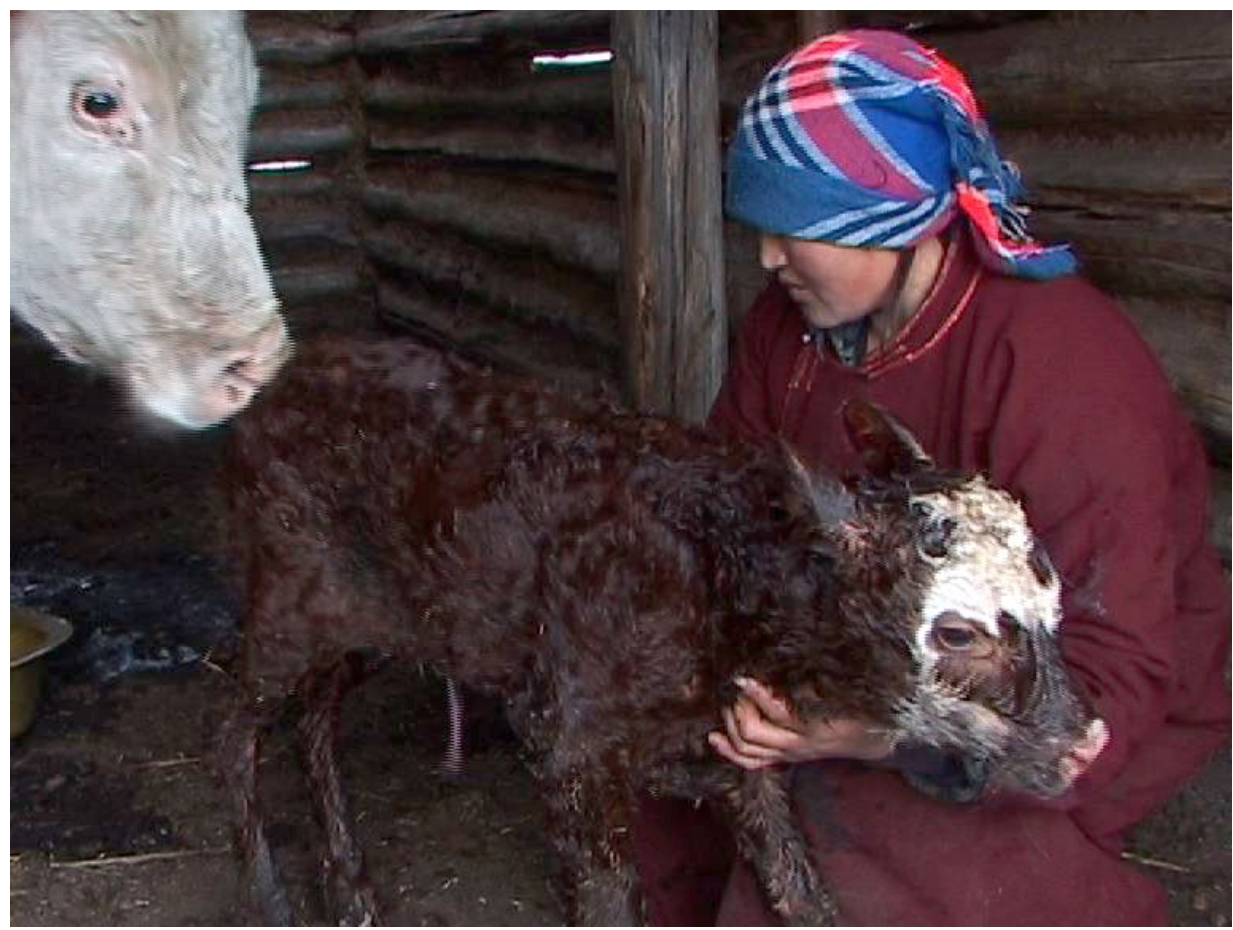

Figure 3 Still image from Khangai Herds Segment 5: 'Lhagva the Herder'

ص View Khangai Herds Segment 5: 'Lhagva the Herder'24

The segment 'Lhagva the Herder' introduces Lhagva and her mother, Dogsomjav, as people, as herding women, and gives an indication of how Lhagva engages with cattle. The other key characters within this sequence are Oodon the cow and her newborn calf, Menget.

The viewer is introduced to Lhagva through her singing to me (perhaps with an audience in mind) behind the video camera. Through this song, my intention was to show the connection of Lhagva with her mother. ${ }^{25}$ The herders I encountered often sang about their herding life and about herd animals, particularly horses. Lhagva's song reveals a reverence towards mothers and their nurturing role. Within this song an 'elegant, dappled-grey horse' is pivotal in assisting to connect the singer with her mother. In the next shot I briefly introduce Dogsomjav as she sits milking a cow and turns towards the camera.

24 View associated media files via the ANU E Press website at http://epress.anu.edu.au/titles/humanitiesresearch-journal-series/humanities-research-vol-xviii-no-1-2012

25 This scene links with another scene within Khangai Herds, where Saikhanaa is also introduced as a character through singing to the camera. 
During my fieldwork I did not record many formal, 'talking-head' interviews, as my aim was to capture the social engagement and behavioural interaction, through both verbal and bodily communication, rather than requiring the viewer to watch a herder just talk about how they engaged with herd animals. In fact, the herders are not inclined to talk about such things, as they have grown up living with herd animals and would be unlikely to think about how they could potentially relate to animals in any other way.

Included here is one of the few interviews I did film and this was towards the end of my year of living in Mongolia, hence I could film without the need for an interpreter. Lhagva had a good idea about what I was interested in, as I had helped her and her mother with the cattle at milking time for many months. I included this interview as it reveals Lhagva's focus on the cows and their calves, rather than on other kinds of herd animals. She explains how she names the calves and how the cows know her as a person, rather than as a stranger. Lhagva's reference to naming the calves and blowing into the ears of newborn calves to assist them links with the birthing scene that follows.

The birth of Menget was the first scene I shot when I was in Dogsomjav's encampment in early spring. The birthing scene begins with a wide shot of the winter shelters to give an indication that the birth is occurring during a snowstorm and in freezing temperatures. Soon after the calf is born, Lhagva blows in the calf's ears and clears the amniotic sac from around the calf's mouth. Lhagva becomes one of the first beings the calf comes into contact with, along with its mother. She talks directly to the calf and checks whether it is a female or male, exclaiming 'it's a girl' and remarks about how long Menget's hooves are while, unperturbed, Oodon loudly guzzles up the surrounding amniotic fluid. Lhagva provides Oodon with some medicinal herbs in milk to give the old cow strength and to assist with the release of the afterbirth. It is important that the calf stands immediately after birth in order to have the ability to suckle from the cow's teats. Lhagva moves the calf around to Oodon's teats to assist the calf to have her first feed.

Lhagva names the calf 'Menget', meaning 'birthmark', as the calf has an unusual mark on her forehead. This name is significant, as birthmarks are auspicious signs to Mongolian herders. The naming of the calf clearly means that Lhagva identifies this calf as having individual characteristics, and attributes the calf with personality. This was an important element that I wanted to convey about the way that Mongolians in the Khangai herd animals, as they treat the herd animals as extensions of the herding family and essentially as 'persons' ${ }^{26}$ 
As a postscript to this scene: Menget was Oodon's eighth and final calf. In the following autumn, Oodon was slaughtered, as she was having trouble eating after losing some of her teeth. Oodon provided the extended family with dried meat over the long, hard winter. This is a good example of the herders' reciprocal relationship with the herd animals, as Lhagva nurtured Oodon's calf to help her to survive the harsh conditions, while Oodon provided essential food for the extended family the following winter. When a family herd animal is slaughtered, it is not displayed publicly. Out of respect for the herding family's beliefs surrounding the slaughter of an animal from the herd, and out of respect for Oodon herself, I refrained from filming the slaughter, even though this would have been valuable for the overall narrative of the sequence and as an indication of the cycle of life in a Mongolian herding encampment.

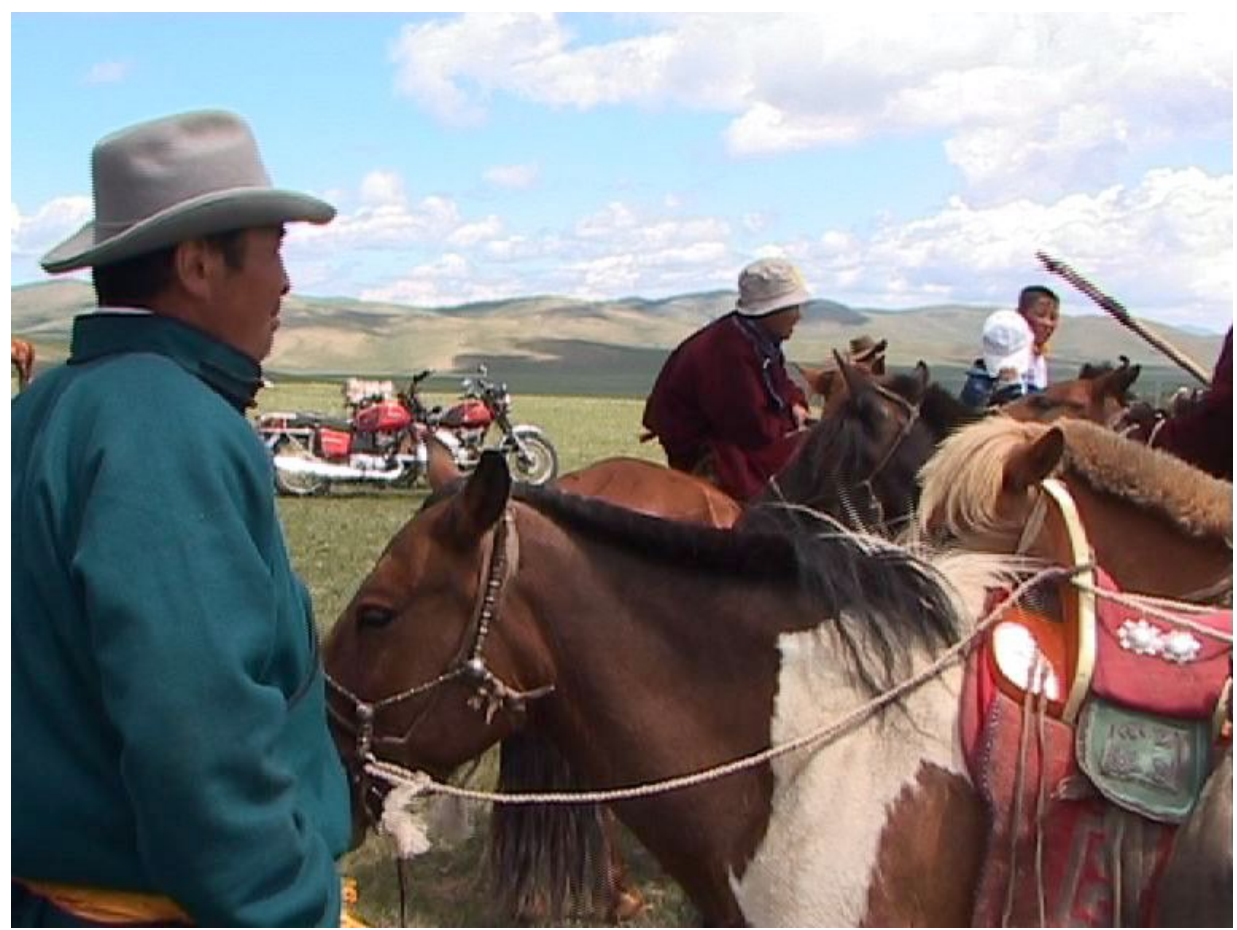

Figure 4 Still image from Khangai Herds Segment 9: 'Training for Naadam'

\section{View Khangai Herds Segment 9: 'Training for Naadam'27}

Naadam, meaning festival in Mongolian, often consists of three sporting events: horseracing, wrestling and archery. My focus, in terms of the Naadam, was on the horseracing and how this reflected the importance of the horse in Mongolian herders' lives.

27 View associated media files via the ANU E Press website at http://epress.anu.edu.au/titles/humanitiesresearch-journal-series/humanities-research-vol-xviii-no-1-2012 
In the first shot, boys are preparing the horses for race training by circling around training poles, while singing a specific racing song to the horses. Boys and horses enter and exit the frame as they circle past me. My camera remains in one position, while encompassing the expanding river valley within the frame. Here, my focus was on the young boys riding the horses and the song they sing, to prepare the horses for racing. The trainer, Ochero, stands to one side, also watching, while the boys walk with their horses into the distance. The boys are then seen galloping past on horseback with the sound of the horses' hooves, the horses' breathing and the boys' calls spurring on the horses during a practise race.

Saikhanaa is again a key person in this sequence and he is training a feisty twoyear-old (or daaga). The training is in preparation for a series of local Naadam but is also a means of breaking in the energetic daaga. I open the main section by introducing the daaga as a character, showing him still nursing from his mother, then Saikhanaa training the daaga to be tethered by a halter. Saikhanaa rides bareback, circling around a corral to warm up the young horse. The pace is slow and measured, with little background noise. We observe as a young boy runs across the frame, playing with a stick, then back again with Saikhanaa trotting on horseback into the distance. There is a sudden burst of action as human and horse gallop past. The unmistakeable sound of the horse's hooves as he gallops towards the camera, and Saikhanaa's calls as he encourages the daaga to go faster, add to the sudden increase in pace. I follow with the camera until Saikhanaa is nearly out of the line of sight, while calls and horse hooves fade into the distance. For me, the gathering cumulus clouds in the distance and the quietness of the scene are very reminiscent of what it felt like in Choijo's encampment, when there was a lull in herding activity during warm afternoons in the late Mongolian summer.

Once back in the encampment, the daaga is coated in sweat and the trainer, Ankhaa, wipes him down with a scraper. This scene is revealing about interspecies engagement, as the daaga is clearly communicating through kicking and shoving with his head that he is not appreciating being scraped down and is not used to this kind of human contact (as he was only recently 'broken in').

A wide shot reveals that the rest of the extended family and visiting relatives are sitting nearby, while Saikhanaa walks the daaga around to cool down. Choijo discusses the upcoming Naadam with the visiting relatives, giving an indication of the organisational structure of a Naadam: horses of different ages race in separate groupings. In this shot I particularly like the interaction in the background, where one of the women, Naraa, is playfully tickling the back of her visiting relative. I continue to record the audio of their discussion in relation to the Naadam while focusing the camera on another trainer, Ganbaa, as he 
returns with a sweaty horse, which is then led to cool down. This introduces Ganbaa as a trainer, which continues in the scene that follows, where he is preparing two horses for a Naadam.

In preparation for a small local Naadam amongst neighbouring herding families, Ganbaa readies the horses for racing by brushing their coats, tying up their tails and holding burning incense beneath their nostrils. Here, the horse opening his mouth to yawn in response to breathing in the incense is a nice moment. Saikhanaa, as jockey, does not participate in this ritual preparation, as this is the role of the trainer. Choijo, as patriarch of the extended family, supervises this preparation and burns juniper incense in a bowl. Here it is quite evident that people have specific roles when it comes to the Naadam: Choijo as patriarch of the encampment, Ganbaa as trainer, Saikhanaa as jockey and the two horses as the prized representatives of the horse herd. Young boys are mainly the ones who ride the horses during training and in races. When older, they in turn become race trainers.

The next scene is the location of the Naadam, which is held by a number of neighbouring herding encampments within the same broad river valley. The men in the extended family encampment, the young boys and I rode together on horseback more than $10 \mathrm{~km}$ to the local Naadam (with my video camera bouncing around behind me in my backpack).

I filmed the race flag at the finish line against a blackened sky and by chance there was a flash of lightning in the distance. This is a beautiful scene but it also meant impending rain and I was not keen for my camera to become drenched. Being a spectator of the horseracing means a long wait, then a sudden rush as the horses and jockeys appear and race over the finish line. The spectators merge with the participants within the race as they whoop and gallop their horses, encouraging the racehorses as they cross over the finish line. After the race the jockeys stand alone, not knowing quite what to do with themselves as trainers take over and scrape the sweat from the racehorses as they continue to circle around to cool down. I stood in the middle with Saikhanaa, filming him as a stationary figure in the centre as the horses and trainers move past him. Here it is evident how the horses are the ones that hold the prestige and are fussed over after the race, not the boys who ride them.

As menacing black clouds the colour of steel continued to build in the background, I shoved my camera in my backpack and we rode back towards our herding encampment. In the middle of the river valley humans and horses were suddenly pelted with hailstones, forcing the herders and myself to shelter in a neighbouring ger until the weather had passed. Luckily I was able to keep my camera gear dry. 
We were all engaging in participant observation, as few (if anyone) were at the local Naadam just as spectators - most had ridden on horseback and were part of an extended family whose members were actively competing in the festival, both in the wrestling and in the horseracing. The Naadam is not just about competitive sporting prowess but also involves the engagement of local herding families and their relationship with their horses. Here was an example of both filmic observation and active participant observation while in the field: humans and horses engaging in a social event, celebrating the stamina and endurance of one another.

\section{Conclusion}

The Doon School project was anthropological research interpreted through film. MacDougall states that few documentaries, or even ethnographic films, constitute original research, yet video is 'uniquely suited to analysing visible cultural forms, the immediacy of individual experience, human relationships with the material world, and social interactions in all their evolving and multivalent complexity'. ${ }^{28}$ I would add that it is also uniquely suited to recording human and non-human relationships.

While filming in the field in Mongolia, my principal filming technique was to leave the camera at a wide angle (avoiding the use of distorting telephoto or macro lenses). This resulted in few close-up shots, unless I was physically close to the subject, and meant that one views the human or non-human as a whole, not a series of separate disconnected parts. My approach with the camera was to represent the herders, herd animals and surrounding landscape as they would be viewed by anyone living in the herding encampment.

Everyone in the herding encampment, both humans and other animals, had specific roles. I would participate with hobbling the cows during milking, herding the sheep and goats, or taking the ox and water cart down to the stream to get water. The extended herding family also recognised that part of what I did was film with a video camera, or take still photos and write up my field notes in the yurt (or ger) at the end of the day. My aim was to incorporate the use of a video camera as part of what I did on a routine basis while living within the herding encampment. And in this context, it seemed to work, as it was seen as just a part of what I did. Perle Mohl describes the integration of representation and fields of knowledge as filmic anthropology, which is 'characterized by the fact that its potential resides in the field and not beyond it'. ${ }^{29}$

28 MacDougall, 'Renewing ethnographic film', p. 15.

29 Mohl, P. 2011, 'Mise en scène, knowledge and participation: considerations of a filming anthropologist', Visual Anthropology, vol. 24, no. 3, p. 228. 
I employed observational filmmaking both as a mode of inquiry and as a means of interpretation. As an approach to filmmaking in the field, observational filmmaking, with its inherent attention to detail, works well in relation to the engagement between humans and other animals. I paid attention to sensory details, such as: the sounds herders make to the herd animals during milking; the physical engagement between a herder and a newborn calf; or the way a horse responds to a rider when training for a race. Recorded through the medium of video, this kind of multi-species engagement conveys a wealth of sensory information. This information, however, comes across very differently using the medium of textual description (as evidenced by my description of the three examples from my Mongolian fieldwork in this paper, if read without the necessary accompanying video segments).

Research focusing on the agency of both humans and other animals is complex particularly when attempting to find a balanced, non-anthropocentric perspective. It is challenging to describe social engagement, bodily communication and emotional attachment between significant others through text. This is where visual mediums, such as video, can be employed as a means of both interpretation and presentation of research material. Video footage provides an alternative means of engagement with humans and other animals as beings-in-the-world.

A multi-species approach to research requires an observational approach to filmmaking, much as both ethnography and ethology are based on observation. The aim is to allow the subjects (both human and non-human) to engage as they ordinarily would with one another. This does not mean that I, as the filmmaker, am an invisible presence, as I may interact with people and other animals from behind the camera in a reflexive manner. The intended result is to produce documentary that is not set up or manipulated by the researcher but is an observation of events as they unfold. This filmmaking process is not intended to be prescriptive but a compelling method for interpreting etho-ethnographicbased research.

Alongside an emerging interest in multi-species ethnography within anthropology, there has been a renewed interest in observational film within ethnographic filmmaking. Grimshaw and Ravetz refer to the current direction of observational cinema in the following way:

The renewed interest in material, emotional or affective, bodily, and sensory ways of being in the world has been critical to our rethinking observational cinema. It has enabled a shift in the terms of debate, away 
from observational filmmaking as a kind of bad science to acknowledge it for what it is - a mode of inquiry that sticks close to lived experience and that seeks to render the finely grained texture of lived experience. ${ }^{30}$

Anna Grimshaw and Amanda Ravetz discuss MacDougall's Doon School Series and a later film, Schoolscapes, ${ }^{31}$ as examples of films that are more experimental and engaged with aesthetics. In a footnote to a review, Anna Grimshaw notes that this sensory and phenomenological approach is evident not only in observational cinema but also in emerging interspecies ethnography. ${ }^{32}$

This orientation towards phenomenology and an attention to bodily and sensory ways of being-in-the-world were my focus when filming the multispecies, multi-sensory, social engagement between herders and herd animals in Mongolia. I could not have foreseen the stylistic turn towards observation and aesthetics in ethnographic filmmaking as a genre, nor the emergence of multi-species ethnography, but it is nice to know that I am not alone in my endeavours. In the future I hope that more researchers take a similar approach and incorporate both of these exciting and emerging areas of anthropology in their research, combining a multi-species approach to research with multisensory etho-ethnographic filmmaking.

30 Grimshaw, A. and Ravetz, A. 2009, Observational Cinema: Anthropology, film and the exploration of social life, Indiana University Press, Bloomington, p. xiv.

31 MacDougall, D. 2007, Schoolscapes, [Film; 77 mins], Ronin Films, Canberra.

32 Grimshaw, 'The bellwether ewe', p. 259. 